\title{
The Effect Of Pollution On Photovoltaic Panels Under Climate Conditions In Hatay
}

\author{
Osman SONSUZ ${ }^{1}$, Ertuğrul ADIGUZEL ${ }^{2 *}$, Rana ORTAC KABAOGLU ${ }^{3}$, Aysel \\ ERSOY YILMAZ ${ }^{4}$ (0)
}

\author{
1, 2, 3,4 Istanbul University - Cerrahpaşa, Electrical and Electronics Engineering Department, 34320, Istanbul, \\ Turkey
}

Geliş / Received: 16/10/2020, Kabul / Accepted: 30/12/2020

\begin{abstract}
In this study, the effect of pollution on monocrystalline and polycrystalline PV panels on short circuit current and open circuit voltage was investigated by external experiments. Experiments were carried out under climate conditions in Hatay province for 210 days from October 2019 to May 2020. In the study, 2 pieces of $45 \mathrm{~W}$ power monocrystalline PV panels and 2 pieces of $50 \mathrm{~W}$ power polycrystalline PV panels were used. PV panels were placed in two groups as manuelly cleaned and uncleaned on the tile roof. One of the monocrystal and polycrystalline panels was cleaned manually for regular periods, while the others were not cleaned except rain. Short circuit current, open circuit voltage, panel surface temperature and radiation values were measured for each panel at certain times during the day, in the morning, at noon and in the evening. In addition, ambient temperature and humidity values were measured and recorded. Environmental factors have been found to affect the short circuit current of the panels, not significantly affecting the open circuit voltage. It has been practically tested that manually cleaned panels have higher short circuit current values than uncleaned panels. Therefore, it has been calculated that cleaning the panels periodically will significantly increase the electricity production in powerful solar power plants. The data obtained as a result of experiments are modeled with artificial neural networks..
\end{abstract}

Keywords: Open Circuit Voltage, Short Circuit Current, Pollution, Panel Cleaning, Artificial Neural Networks.

\section{Hatay İklim Şartları Altında Oluşan Kirliliğin Fotovoltaik Paneller Üzerindeki Etkisi}

\section{Öz}

Bu çalışmada, monokristal ve polikristal PV panellerdeki kirliliğin kısa devre akımı ve açık devre gerilimi üzerindeki etkisi, dış ortamda yapılan deneyler ile incelenmiştir. Deneyler Ekim 2019'dan Mayıs 2020'ye kadar 210 gün boyunca Hatay ilindeki iklim şartları altında yapılmıştır. Çalışmada 2 adet $45 \mathrm{~W}$ gücünde monokristal PV panel ve 2 adet $50 \mathrm{~W}$ gücünde polikristal PV panel kullanılmıştır. PV paneller kiremitli çatı üzerine el ile temizlenmiş ve temizlenmemiş olarak iki gruba ayrılarak yerleştirilmiştir. Monokristal ve polikristal panellerden birer tanesine düzenli aralıklarla elle temizleme işlemi yapılmıştır, diğerlerine ise yağmur dışında hiçbir temizleme işlemi yapılmamıştır. Sabah, öğle ve akşam olmak üzere gün içindeki belirli saatlerde her bir panel için kısa deve akımı, açık devre gerilimi, panel yüzey sıcaklığı ve ışınım değerleri ölçülmüştür. Ayrıca ortam sıcaklığı ve nem değerleri de ölçülerek kayıt altına alınmıştır. Çevresel faktörlerin panellerin kısa devre akımını etkilediği, açık devre gerilimini önemli bir miktarda etkilemediği bulunmuştur. El ile temizlenmiş panellerin temizlenmemiş panellere göre kısa devre akımı değerlerinin daha fazla olduğu uygulamalı olarak test edilmiştir. Bundan dolayı panellerin belirli periyotlarla temizlenmesinin büyük güçlü güneş enerjisi santrallerindeki elektrik üretimini önemli miktarlarda artıracağı hesaplanmıştır. Deneyler sonucu elde edilen veriler yapay sinir ağları ile modellenmiştir.

Anahtar Kelimeler: Açık Devre Gerilimi, Kısa Devre Akımı, Kirlilik, Panel Temizliği, Yapay Sinir Ağları. 


\section{Introduction}

Our presence in the age of technology and the rapidly increasing population of countries have increased the demand for energy. The fact that fossil fuels enter the depletion phase and cannot supply the increasing energy demand has increased the investments of countries in renewable energy systems over the years. Solar energy, which is one of the renewable energy technologies, has increased its popularity in recent years due to its ease of maintenance and use (Öztürk, 2013). Solar energy is used in areas such as heating and cooling of residences and workplaces, hot water production, heating of greenhouses, agricultural irrigation (Varınca and Gönüllü, 2006).

While the installed power of solar power plants around the world was $100,8 \mathrm{GW}$ in 2012 , it reached $627 \mathrm{GW}$ by increasing about six times at the end of 2019. In the coming years, in parallel with the development of production technologies, energy investments are expected to increase even more. According to the expectations of the European Photovoltaic Industry Association SolarPower Europe for 2023, the total installed power will reach $1.043 \mathrm{GW}$ according to the lowest scenario and 1.610 GW according to the highest scenario (Solar Power, 2019).

At the end of 2019, according to data released by the TEİAŞ gross electricity consumption in Turkey was 303.674 GWh (teiaş web, 2020). Looking at the electricity production data, the gross electricity production at the end of 2019 reached 304.252 GWh (teiaş web, 2020). Our country has supported energy investments to supply the increasing energy demand in recent years. At the end of 2019 the installed capacity of power plants in Turkey reached 91,3 GW. In resource-based installed power distribution, solar energy constitutes $6,57 \%$ of the total installed power with 5.995 MW power. As of the end of 2019, the number of solar power plants has increased to 6.901 (teiaş web, 2020). This number is expected to increase in the coming years with the technological developments and the decrease in production costs.

Photon particles from the sun can be directly converted into electrical energy by means of photovoltaic cells. The power produced by a photovoltaic cell depends on the amount of radiation reaching the solar cells. Many environmental factors determine the ideal power output or optimum efficiency of the photovoltaic cell (Maghami et al., 2016).

External factors such as humidity, temperature, climate, wind, dust and rain are among the factors affecting panel efficiency. Although our country has an average of 7,5 hours of sunbathing per day, it has a lot of such external factors due to its different climate types (enerji.gov web, 2020). Dust, dirt and pollen carried by the wind and water stains caused by rain water pollute the glass surface on the panels over times. The resulting pollution prevents photons from the sun from reaching the photovoltaic cell, reducing the efficiency of photovoltaic panels.

The accumulation of dust particles on the panels degrades the performance of solar cells and causes significant losses in the power produced by preventing the solar radiation falling on the surface of the solar panel. After a certain time, solar power plants are significantly affected by dust accumulation. Especially large-scale solar power plants are highly affected by dust accumulation. If this 
effect is ignored, there is a big difference between the actual and estimated energy efficiency of the power plants (Saidan et al., 2016).

Dust accumulation depends on environmental factors such as the angle of inclination of the solar collector, duration of exposure, climatic conditions, wind and dust characteristics. Also, the surface material of PV panels can significantly affect dust accumulation. he polycrystalline silicon module packaged with epoxy degrades faster under the same powder concentration than other modules with a glass surface (Jiang et al., 2011).

Besides the material and design parameters, there are environmental factors such as dust, humidity and air velocity that can affect the performance of the PV cell. Humidity causes a decrease in photovoltaic battery efficiency. High wind speed provides better efficiency by reducing the relative humidity of atmospheric air. At the same time, the high temperature of the panel surface decreases with the increasing wind speed. The wind scatters the dust into the environment, causing the photovoltaic cells to shade and reduce their performance (Mekhilef et al., 2012).

Boyle et al. investigated the effect of natural pollution on photovoltaic panels in the Colorado region. It has been determined that there is a linear relationship between dust accumulation and light transmittance and it has been concluded that every 1 gram of dust accumulated per square meter reduces the light transmittance by $4,1 \%$. In addition, it has been determined that dust accumulates on PV panels between $1 \mathrm{mg}$ and $50 \mathrm{mg}$ per square meter under Colorado climate conditions. It has been observed that the accumulated dust can be seen when it is over $2 \mathrm{~g}$ per square meter (Boyle et al., 2015).
Adinoyi and Said conducted a study on the effect of dust accumulation on the power output of PV modules in Dhahran province in eastern Saudi Arabia. According to their experimental results, it has been determined that a single dust storm can reduce the power output of the photovoltaic module by up to $20 \%$. It has been concluded that if cleaning is not carried out on photovoltaic modules for a period of more than six months, power output may decrease by more than 50\%. They recommended that solar panels should be cleaned at least once every two weeks, and when a sandstorm occurs, it should be cleaned immediately (Adinoyi and Said, 2013).

According to the results of the study carried out by Klugmann-Radziemska in Gdansk, Poland, it has been determined that one micrometer natural dust thickness reduces the efficiency of photovoltaic systems by $25,5 \%$. She also stated that the physical properties of the dust may depend on geographic area and environmental conditions (KlugmannRadziemska, 2015).

Kazem and Chaichan investigated the energy losses caused by dust accumulation in PV modules in Oman. Experiments were conducted over three months to evaluate the physical properties of six dust samples collected from six different locations in northern Oman. It has been found that the diameter of $64 \%$ of the dust particles varies between 2 and $63 \mu \mathrm{m}$, and the dust accumulation on the PV modules varies according to the location. It has been determined that there is a decrease of up to 35$40 \%$ in the efficiency of the PV module after being exposed to weather conditions for more than three months (Kazem and Chaichan, 2016). 
Appels et al, arguing that the studies conducted to measure the impact of pollution on the panels are mostly in the Middle East, and conducted their studies in Belgium, located in the European continent. The experimental results showed that the impact of the pollution on the panels is not as severe as in the Middle East. It has been found that precipitation only has a cleaning effect on larger dust particles (pollen, $60 \mu \mathrm{m}$ ), with little or no cleaning effect on small dust particles (2-10 $\mu \mathrm{m})$ (Appels et al., 2013).

Urrejola et al., as a result of their two-year experiment in Santiago, the capital of Chile, suggested a 45-day cleaning period regardless of the cleaning and energy prices. At the same time, they determined that the dust accumulation formed in Santiago climate conditions lost the performance of PV panels between $0,13 \%$ and $0,56 \%$ daily (Urrejola et al., 2016).

Rao et al., conducted experiments indoors and outdoors in India to examine the effect of dust deposits on the performance of PV panels. According to the results of their experiments, it has been determined that dust accumulation does not significantly affect the open circuit voltage. However, they found that short circuit current was affected $30-40 \%$ in indoor experiments and 4-5\% in outdoor experiments (Rao et al., 2014).

Zaihidee et al., found in their studies that 20 grams of dust accumulated in one square meter of PV panel reduced short circuit current by $15-21 \%$, open circuit voltage by 2 $6 \%$ and efficiency by $15-35 \%$. They found that the dust accumulated on the panels reduced the incoming solar radiation and surface permeability, applied partial shading effect, and also caused the efficiency of the
PV panel to deteriorate by increasing the panel temperature (Zaihidee et al., 2016).

In this study, the most sold monocrystalline (2 pieces) and polycrystalline (2 pieces) PV panels in the solar energy market were established in Yayladağ 1 district of Hatay province. One of the monocrystalline and polycrystalline panels was cleaned regularly. The remaining ones, on the other hand, were not cleaned at all, except for rain, under the conditions of the Mediterranean climate of Hatay province. The data obtained after the tests on PV panels are modeled in Artificial Neural Networks.

\section{Material and Methods}

\subsection{Material}

45 Watt monocrystalline photovoltaic panels (2 pieces) and 50 Watt polycrystalline photovoltaic panels ( 2 pieces) were used to examine the effect of pollution on photovoltaic panels under climatic conditions in the province of Hatay. Cleaning was done regularly on one of the monocrystalline and polycrystalline panels, while no cleaning was done on the others. The surfaces of the polycrystalline and monocrystalline panels that need to be cleaned manually were cleaned with a non-marking glass cleaner before each measurement. Figure 1 shows the locations of the clean and dirty panels on the roof. Pyranometer (CEM, DT-1307) was used to measure the radiation values coming to the surface of photovoltaic panels. The surface temperature of each photovoltaic panel was measured with the aid of a non-contact infrared thermometer (ACURA, AC-9270). Ambient temperature and humidity were measured with a digital temperature humidity thermometer (HTC-2). Short-circuit currents and open-circuit voltages of panels were measured and recorded periodically with the 
help of a digital multimeter (TWINTEX, TM199) over an 8-terminal block to which the positive (+) and negative (-) ends of the panels are connected.

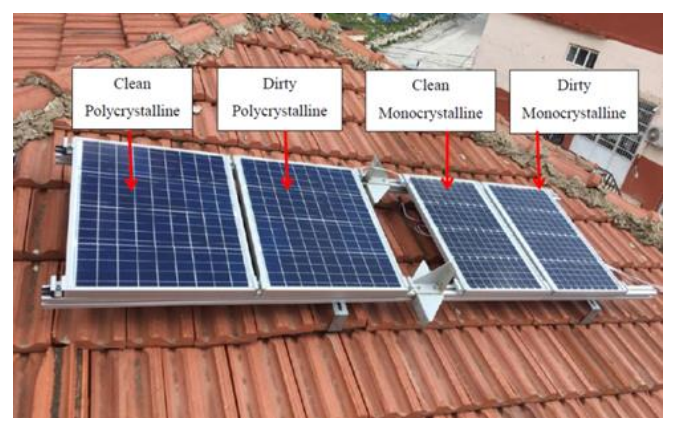

Figure 1: The views of the panels on the roof.

\subsection{Method}

In the thesis study, the effect of the pollution in the photovoltaic panels formed in the climatic conditions of the province of Hatay was examinedwith limited data. In order to evaluate the impact of pollution for environmental factors occurring in different time periods, the obtained data were modeled with artificial neural networks. Artificial neural networks; They are systems developed by using the working principle of the human brain nervous system, that can generate new information by using the learning function, have its own internal memory, and automatically solve new situations according to past experiences. In short, it is the imitation of the nervous system with software programs in the computer environment. In addition, its coverage area is expanding and growing today (Uztemur, 2019).

Artificial neural networks have been active in different fields in the scientific world as a result of their features such as learning the problem, showing the same reaction to the examples that they did not encounter during training, solving nonlinear problems, adaptability, tolerance to errors, hardware, fast information processing, analysis and design convenience. Thanks to these features, it continues to be used in solving problems in application areas such as failure analysis and detection, medicine, defense industry, communication, production, automation and control, statistics and finance (Fausett, 1994).

Artificial neural network modeling was done separately for clean polycrystalline, dirty polycrystalline, clean monocrystalline and dirty monocrystalline photovoltaic panels. For each modeling, 137 pieces data were used, which were measured at certain periods for 210 days. $70 \%$ of the data set was used in the training phase, $15 \%$ in the verification phase, and $15 \%$ in the test phase.

All data obtained are normalized to reduce the error rates in the artificial neural network. The min-max normalization method has been chosen as the normalization method. According to the formula given in Equation 1, all data are reduced to 0-1 interval.

$x^{i}=\frac{x-x_{\text {min }}}{x_{\max }-x_{\min }}$

$\mathrm{x}^{\mathrm{i}}=$ Normalized data

$\mathrm{x}=$ Data to normalize

$\mathrm{x}_{\max }=$ The largest value in the data set

$\mathrm{x}_{\min }=$ Smallest value in data set

The artificial neural network models were prepared with the nntool function of the MATLAB program. The artificial neural network architecture shown in Figure 2 was used for each modeling. The input layer of the artificial neural network is composed of air temperature, humidity, radiation and panel surface temperature data. Output layers are composed of short circuit current and open circuit voltage data of photovoltaic panels. In order for artificial neural network models to make successful predictions, various numbers 
of hidden neurons have been tested while creating models. When the number of neurons in the hidden layer was determined as 10 , it was determined that the modeling that made the most successful prediction was performed. As seen in Figure 2, the artificial neural network models created are among the feed forward network models. When evaluated according to the number of layers, the artificial neural networks created are multilayered due to their hidden layer. In all artificial neural network models, the most commonly used mentored learning method in the literature was used.

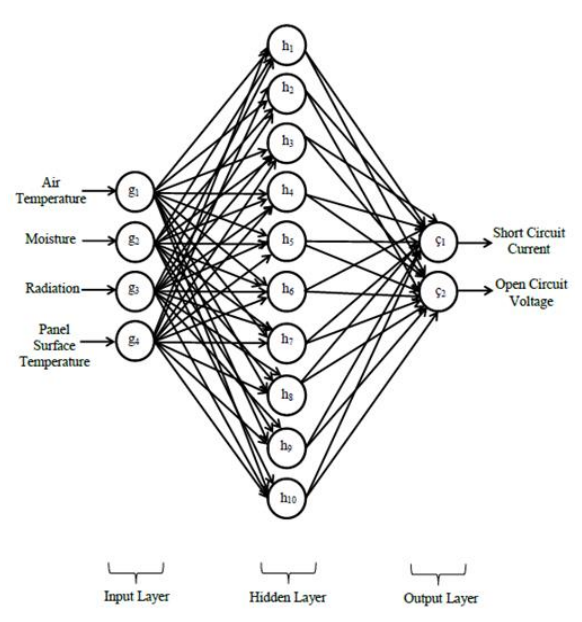

Figure 2: Generated ANN structure.

Four different ANN models were created by selecting the same functions. Feed forward back propagation network has been chosen as the network type in artificial neural network models. Levenberg-Marquand (trainlm), which adjusts the weight and threshold values, was preferred as the training algorithm because of its fast and successful results. Learngdm was chosen as the learning function. Correlation coefficient and mean square error (MSE) were used to evaluate the performance of artificial neural networks. The tansig transfer function, which is the hyperbolic tangent function, was set as the activation function because it gave successful correlation values.

\section{Findings}

\subsection{Experimental Results}

Photovoltaic panels were installed on the roof facing the south facade of the cafeteria building of Yavuz Sultan Selim Han Vocational and Technical Anatolian High School in Yayladağ 1 district of Hatay province. One of the monocrystal and polycrystalline panels was cleaned manually for regular periods, while the others were not cleaned except rain. The data on clean and dirty photovoltaic panels were measured and recorded for 210 days three times a day, in the morning, noon and evening, between 23 October 2019 and 20 May 2020. Open circuit voltage and short circuit current data of monocrystalline and polycrystalline panels were taken as a criterion to examine the effect of environmental factors on photovoltaic panels. At the end of 210 days, average short circuit currents and open circuit voltage values of the panels are given in Table 1 . In Figure 3 and Figure 4, day-dependent values of the short circuit current and open circuit voltages of clean and dirty photovoltaic panels in the morning, noon and evening times are given.

Table 1: Average short circuit currents and open circuit voltage values of photovoltaic panels.

\begin{tabular}{|c|c|c|}
\hline PV Type & $\begin{array}{c}\text { Short } \\
\text { Circuit } \\
\text { Current }\end{array}$ & $\begin{array}{c}\text { Open } \\
\text { Circuit } \\
\text { Voltage }\end{array}$ \\
\hline $\begin{array}{c}\text { Clean Polycrystalline } \\
(50 \mathrm{~W})\end{array}$ & $1,599 \mathrm{~A}$ & $20,986 \mathrm{~V}$ \\
\hline $\begin{array}{c}\text { Dirty Polycrystalline } \\
(50 \mathrm{~W})\end{array}$ & $1,558 \mathrm{~A}$ & $20,055 \mathrm{~V}$ \\
\hline $\begin{array}{c}\text { Clean Monocrystalline } \\
(45 \text { W) }\end{array}$ & $1,207 \mathrm{~A}$ & $21,641 \mathrm{~V}$ \\
\hline $\begin{array}{c}\text { Dirty Monocrystalline } \\
(45 \mathrm{~W})\end{array}$ & $1,183 \mathrm{~A}$ & $21,609 \mathrm{~V}$ \\
\hline
\end{tabular}



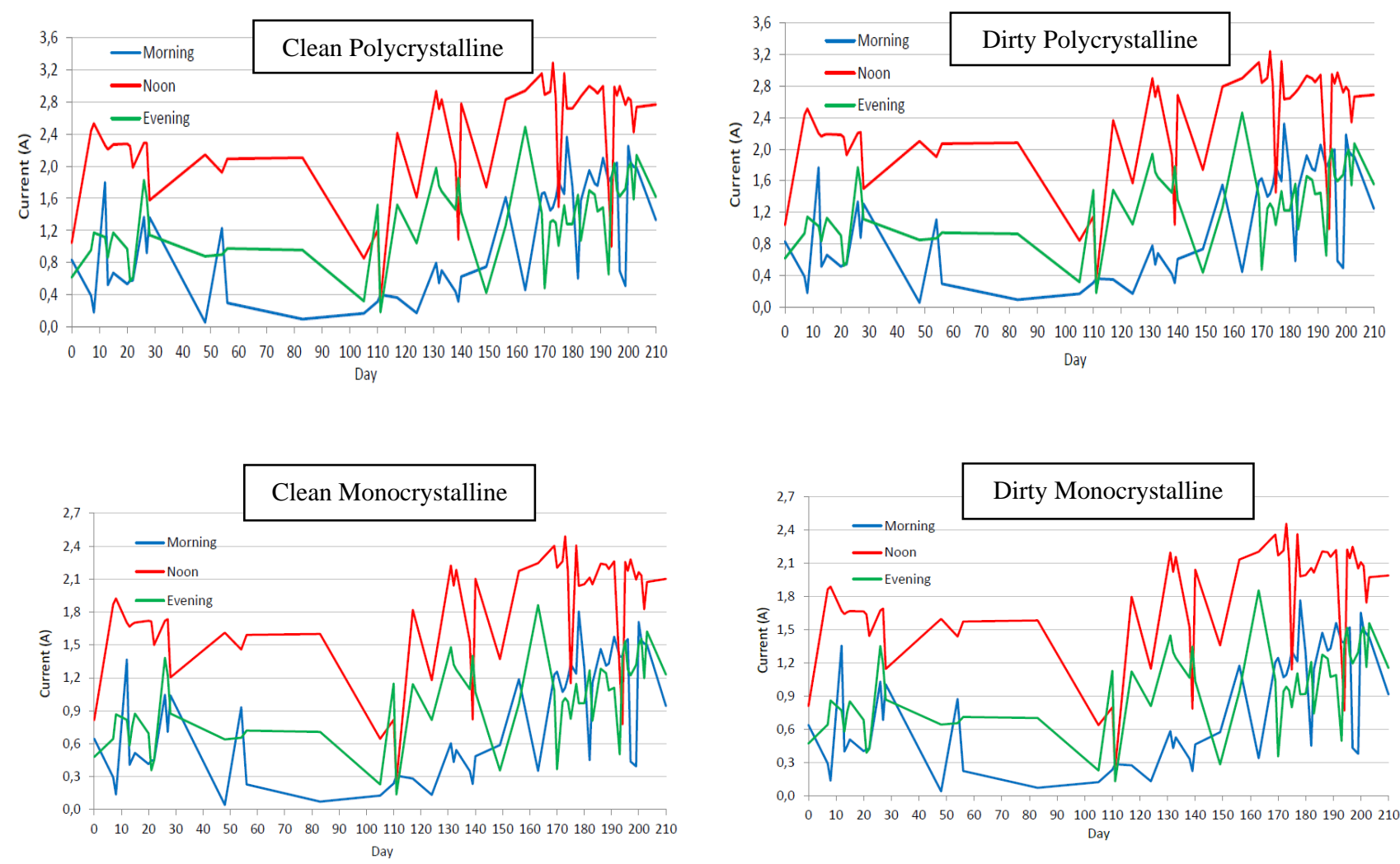

Figure 3. Short circuit current-time graphs of photovoltaic panels
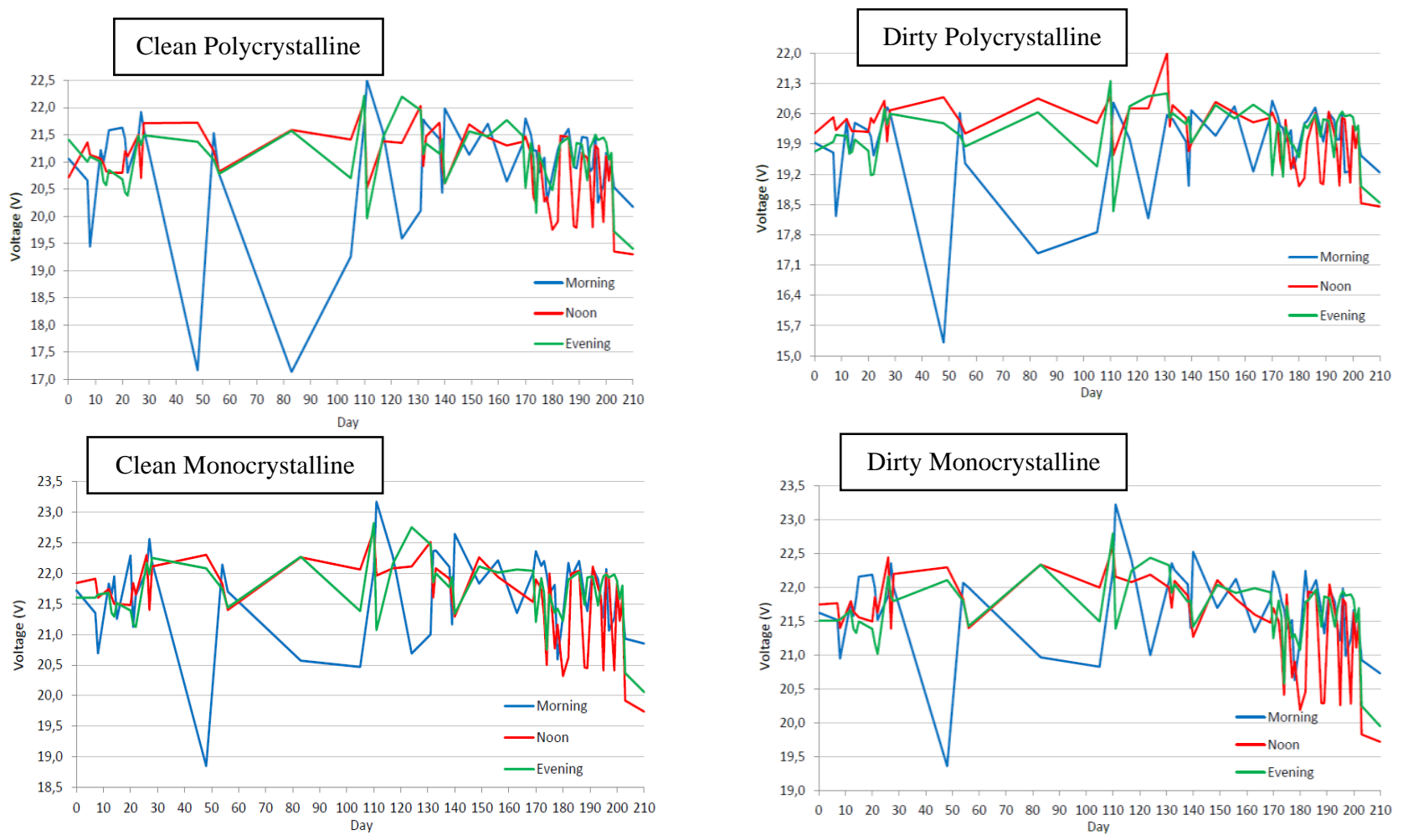

Figure 4. Open circuit voltage-time graphs of photovoltaic panels 


\subsection{ANN Results}

In this section, the results of the artificial neural network modeling created for each panel are given. In Table 2, the correlation coefficient values of all the training, verification and test stages of the artificial neural network modeling were given. In addition, MSE (mean square error) values of the output data of ANN are given. In Figure 5 and Figure 6, the short circuit current and open circuit voltage values predicted by the artificial neural network are compared with the data measured in the experimental study. Looking at the graphics, it is seen that the values predicted by ANN are highly compatible with the actual values.

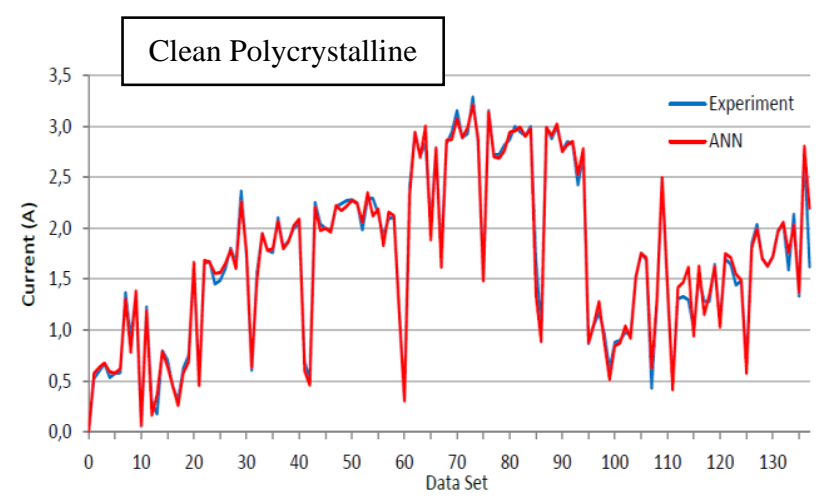

Table 2: Correlation coefficients and mean square error values of ANN models

\begin{tabular}{|c|c|c|}
\hline PV Type & $\begin{array}{c}\text { Correlation } \\
\text { Coefficients }\end{array}$ & MSE \\
\hline $\begin{array}{c}\text { Clean Polycrystalline } \\
(50 \mathrm{~W})\end{array}$ & 0,98395 & 0,039 \\
\hline $\begin{array}{c}\text { Dirty Polycrystalline } \\
(50 \mathrm{~W})\end{array}$ & 0,9873 & 0,041 \\
\hline $\begin{array}{c}\text { Clean Monocrystalline } \\
(45 \mathrm{~W})\end{array}$ & 0,98054 & 0,028 \\
\hline $\begin{array}{c}\text { Dirty Monocrystalline } \\
(45 \mathrm{~W})\end{array}$ & 0,98842 & 0,012 \\
\hline
\end{tabular}
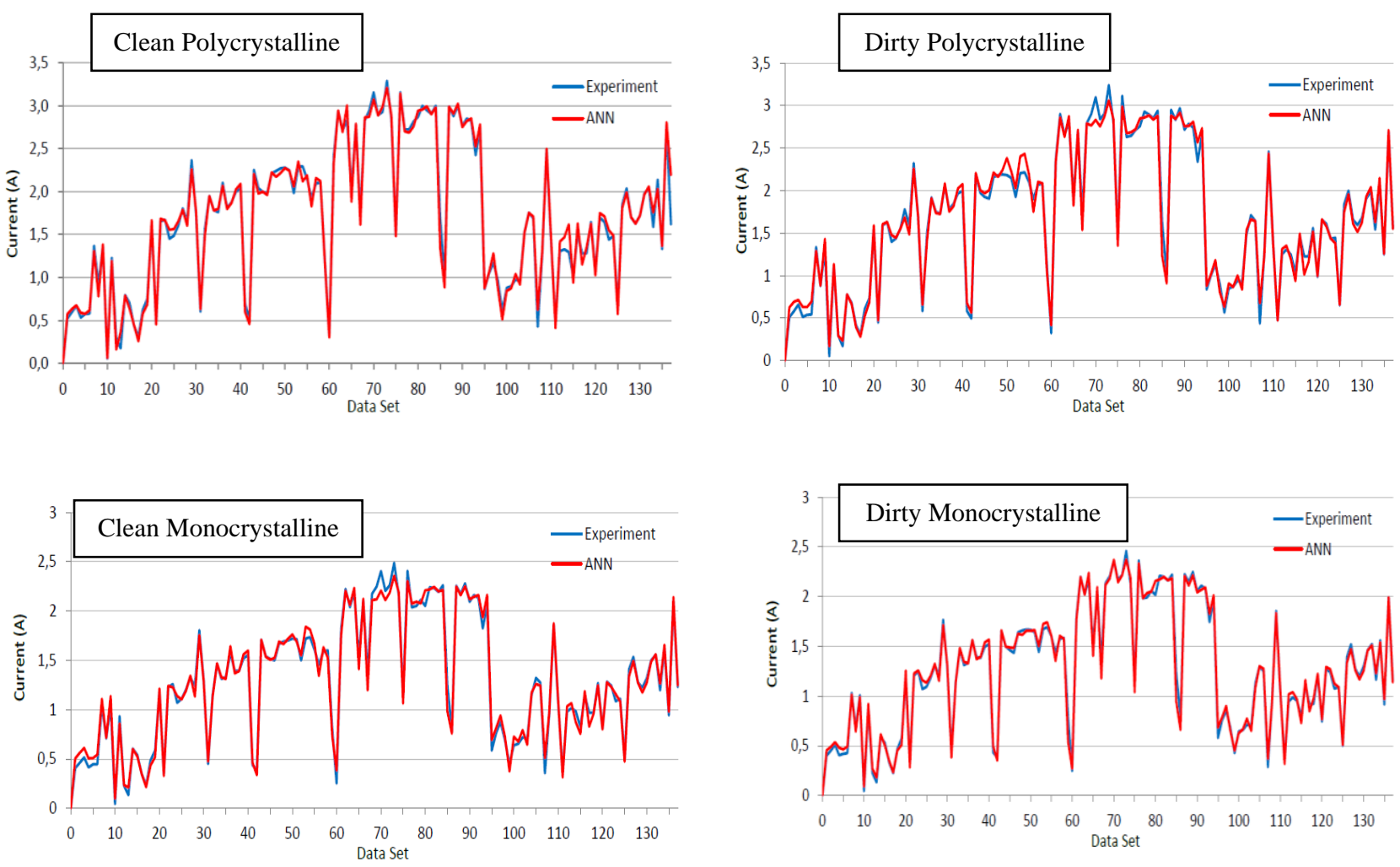

Figure 5. Comparison of short circuit current measurement values of photovoltaic panels and ANN predicted values. 

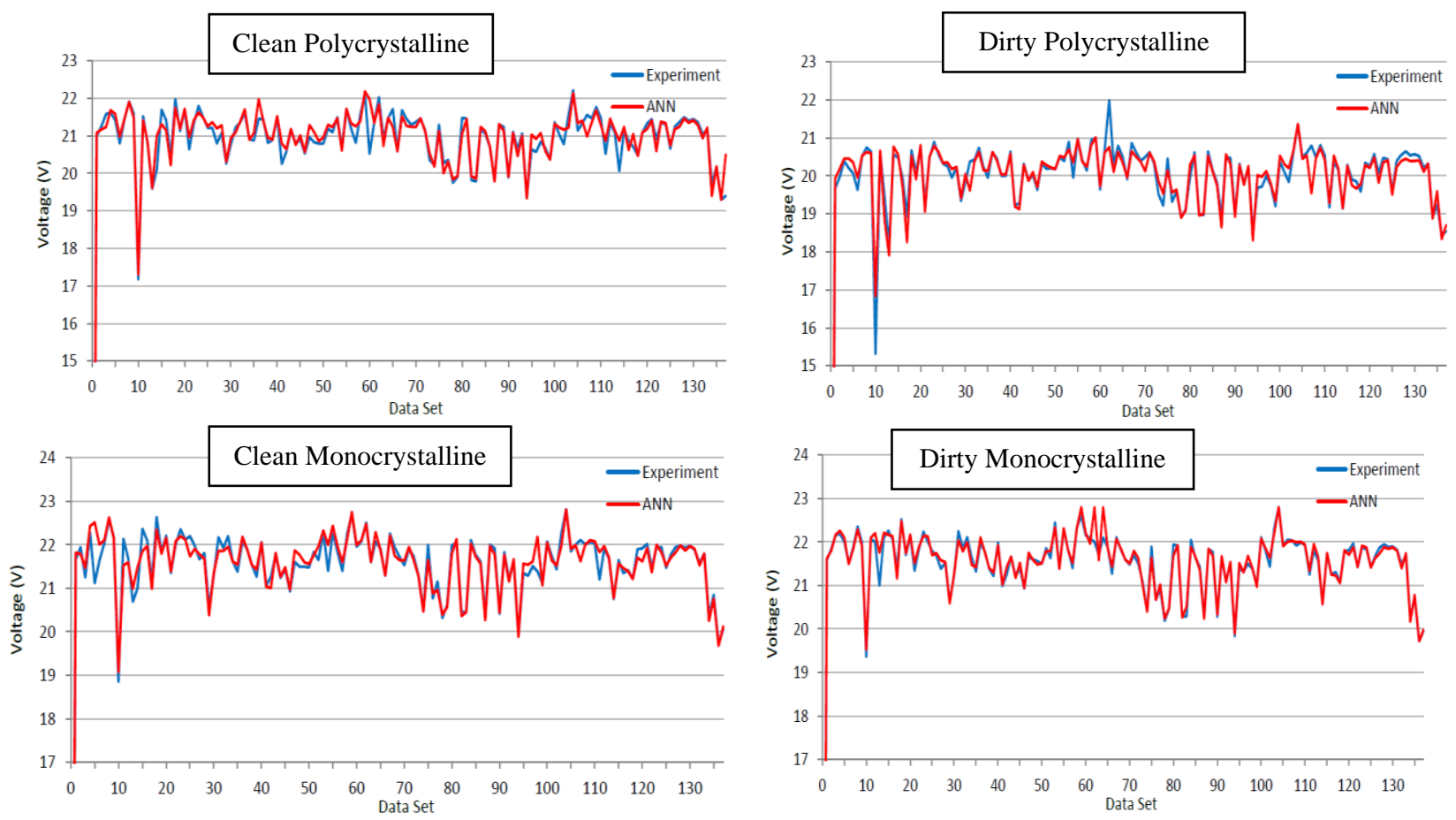

Figure 6. Comparison of open circuit voltage measurement values of photovoltaic panels and ANN predicted values.

\section{Discussion and Conclusion}

When the graphics were evaluated, the short circuit current values of clean photovoltaic panels were higher than the dirty photovoltaic panels in all measurements. The reason for the short circuit current difference between the two panels is that the dust accumulated on the panel surface prevents the solar radiation falling on the PV cell. Dirty polycrystalline panel lost an average of $2,7 \%$ short circuit current at the end of 210 days compared to clean polycrystalline panel. The dirty monocrystalline panel has lost an average of $2,08 \%$ short circuit current at the end of 210 days compared to the clean monocrystalline panel. Conducting experimental studies in months when the number of rainy days is high caused the losses in short circuit currents to remain relatively low.

When the open circuit voltages of monocrystalline photovoltaic clean and dirty panels were evaluated, small amounts of voltage losses were revealed. The dirty monocrystalline panel has lost an average of $0,15 \%$ open circuit voltage at the end of 210 days compared to the clean monocrystalline panel. The reason for this can be said that the open circuit voltage changes by the panel surface temperature. The calculation of the average surface temperature difference of $0,42 \%$ between the clean and dirty monocrystalline panel supports this situation.

When the open circuit voltages of polycrystalline photovoltaic clean and dirty panels are evaluated, high losses were calculated compared to monocrystalline panels. Dirty polycrystalline panel lost an average of $4,65 \%$ open circuit voltage at the end of 210 days compared to clean polycrystalline panel. It is thought that the reason for this is that high voltage losses occur due to the error arising during the production phase. As proof of this situation, it can be shown that both polycrystalline panels produce different open circuit voltage values although they produce equal short circuit current values under the same conditions. 
When we look at the correlation coefficients and MSE values in Table 2, which are the criteria for evaluating the performance of ANN, the fact that the correlation coefficients are close to 1 and the mean square error (MSE) is close to 0, showing that there is a strong relationship between the real measurement values and the values predicted by artificial neural networks.

As a result of this experimental study, it was determined that the dust accumulated on the panel surfaces prevented the radiation falling on the PV cell, affecting the short circuit currents of the panels more and the panel cleaning increased the short circuit current values. It has been calculated that cleaning the panels in Hatay at short-term intervals will significantly increase the electricity production in large powerful solar power plants, but considering the cleaning and labor costs, the increased electricity generation will not cover the cost.

As a result of the experimental study, it is possible to estimate the electricity generation of the solar power plants in Hatay, where clean and dirty monocrystalline and polycrystalline panels are installed, with the ANN models created for each panel. In addition, thanks to the measurements made at three different hours of the day, appropriate panel cleaning periods in solar power plants can be determined.

\section{References}

Öztürk, H., 2013, Yenilenebilir Enerji Kaynakları, Birsen Yayınevi, İstanbul.

Varınca, K., Gönüllü, M.T., Türkiye'de Güneş Enerjisi Potansiyeli ve $\mathrm{Bu}$ Potansiyelin Kullanım Derecesi, Yöntemi ve Yaygınlığı Üzerine Bir Araştırma, I.
Ulusal Güneş ve Hidrojen Enerjisi Kongresi, 21-23 Haziran 2006, Eskişehir.

SolarPower Europe, 2019, Global Market Outlook For Solar Power 2019-2023, Brussels, ISBN: 9789082714326.

https://www.teias.gov.tr/tr-TR/rakamlarlaelektrik-iletimi (Ziyaret Tarihi: 17.03.20).

https://www.teias.gov.tr/tr-TR/aylik-

elektrik-uretim-tuketim-raporlari (Ziyaret Tarihi: 17.03.20).

https://www.teias.gov.tr/tr-TR/kurulu-gucraporlari (Ziyaret Tarihi: 17.03.20).

Maghami, M.R., Hizam, H., Gomes, C., Radzi, M.A., Rezadad, M.I., Hajighorbani, S., 2016, Power loss due to soiling on solar panel: A review, Renewable and Sustainable Energy Reviews, 59, 13071316.

http://www.enerji.gov.tr/tr/Sayfalar/Gunes (Ziyaret Tarihi: 16.03.20).

Saidan, M., Albaali, A.G., Alasis, E., Kaldellis, J.K., 2016, Experimental study on the effect of dust deposition on solar photovoltaic panels in desert environment, Renewable Energy, 92, 499-505.

Jiang, H., Lu, L., Sun, K., 2011, Experimental investigation of the impact of airborne dust deposition on the performance of solar photovoltaic (PV) modules, Atmospheric Environment, 45, 4299-4304.

Mekhilef, S., Saidur, R., Kamalisarvestani, M., 2012, Effect of dust, humidity and air velocity on efficiency of photovoltaic cells, Renewable and Sustainable Energy Reviews, 16, 2920-2925.

Boyle, L., Flinchpaugh, H., Hannigan, M.P., 2015, Natural soiling of photovoltaic cover plates and the impact on transmission, Renewable Energy, 77, 166-173. 
Adinoyi, M.J., Said, S.A.M., 2013, Effect of dust accumulation on the power outputs of solar photovoltaic modules, Renewable Energy, 60, 633-636.

Klugmann-Radziemska, E., 2015, Degradation of electrical performance of a crystalline photovoltaic module due to dust deposition in northern Poland, Renewable Energy, 78, 418-426.

Kazem, H.A., Chaichan, M.T., 2016, Experimental analysis of the effect of dust's physical propertieson photovoltaic modules in Northern Oman, Solar Energy, 139, 68- 80.

Appels, R., Lefevre, B., Herteleer, B., Goverde, H., Beerten, A., Paesen, R., Medts, K.D., Driesen, J., Poortmans, J., 2013, Effect of soiling on photovoltaic modules, Solar Energy, 96, 283-291.

Urrejola, E., Antonanzas, J., Ayala, P., Salgado, M., Ramirez-Sagner, G., Cortes, C., Pino, A., Escobar, R., 2016, Effect of soiling and sunlight exposure on the performance ratio of photovoltaic technologies in Santiago, Chile, Energy Conversion and Management, 114, 338-347.

Rao, A., Pillai, R., Mani, M., Ramamurthy, P., 2014, Influence of dust deposition on photovoltaic panel performance, Energy Procedia, 54, 690-700.

Zaihidee, F.M., Mekhilef, S., Seyedmahmoudian, M., Horan, B., 2016, Dust as an unalterable deteriorative factor affecting PV panel's efficiency: Why and how, Renewable and Sustainable Energy Reviews, 65, 1267-1278.

Uztemur, M., 2019, Yapay Sinir Ağları ile Optik Karakter Tanıma, Yüksek Lisans, İstanbul Teknik Üniversitesi, Fen Bilimleri Enstitüsü.
Fausett, L., 1994, Fundamentals of neural networks: architectures, algorithms, and applications, Prentice-Hall, Inc.. 